\title{
Kualitas hidup manusia lanjut usia pengguna gigi tiruan di Kecamatan Wanea
}

\author{
${ }^{1}$ Nikita S. W. Massie \\ ${ }^{2}$ Vonny N. S. Wowor \\ ${ }^{3}$ Lydia Tendean
}

\author{
${ }^{1}$ Kandidat Skripsi Program Studi Pendidikan Dokter Gigi Fakultas Kedokteran \\ ${ }^{2}$ Program Studi Pendidikan Dokter Gigi Fakultas Kedokteran \\ ${ }^{3}$ Bagian Biologi Fakultas Kedokteran \\ Universitas Sam Ratulangi Manado \\ Email: nikita.massie@yahoo.co.id
}

\begin{abstract}
A qualified life is the hope of every elderly, which means that they can enjoy they elderly life happily. Tooth loss can cause dysfunction that affect the quality of life. Well-made denture can replace the missing teeth and restore the dysfunction. This study aimed to obtain the life quality of elderly at Kecamatan Wanea. This was a descriptive study with a cross sectional design. Population in this study consisted of elderly as many as 329 people that used dentures. The total samples were 77 respondents obtained by using purposive sampling method. This study was carried out at Kecamatan Wanea from February till August 2016. OHIP 14 quitionary was used as the instrument in this study. The life quality measurement score showed that the functional limitation dimension was 151.5; physical disability dimension was 140; psychical disability dimension was 106; social disability dimension was 99.5 ; hampered dimension was 102.5; and life quality measurement score was 122.7 . Conclusion: The life quality of elderly using dentures at Kecamatan Wanea was quite good.
\end{abstract}

Keywords: life quality, elderly, denture user.

\begin{abstract}
Abstrak: Hidup yang berkualitas merupakan sesuatu yang diinginkan lansia sehingga bisa menikmati masa tua dengan penuh makna, membahagiakan, dan berguna. Kehilangan gigi dapat menimbulkan gangguan fungsi yang berpengaruh pada kualitas hidup. Gigi tiruan yang dibuat dengan baik untuk menggantikan gigi yang hilang dapat memulihkan fungsi yang terganggu, dan akan berdampak pada kualitas hidup penggunanya. Penelitian ini bertujuan untuk mengetahui kualitas hidup manusia lanjut usia pengguna gigi tiruan di Kecamatan Wanea. Jenis penelitian ini ialah deskriptif dengan desain potong lintang. Populasi penelitian ini ialah lansia yang memakai gigi tiruan sebanyak 329 orang. Sampel berjumlah 77 lansia yang diperoleh dengan metode purposive sampling. Penelitian dilakukan di Kecamatan Wanea pada bulan Febuari sampai dengan Agustus 2016. Penelitian ini menggunakan instrumen berupa kuesioner OHIP 14. Hasil penelitian menunjukkan skor pengukuran kualitas hidup berdasarkan dimensi keterbatasan fungsi sebesar 151,5; dimensi rasa sakit fisik sebesar 148; dimensi ketidaknyamanan psikis sebesar 112; dimensi ketidakmampuan fisik sebesar 140; dimensi ketidakmampuan psikis sebesar 106; dimensi ketidakmampuan sosial sebesar 99,5; dimensi keterhambatan sebesar 102,5; dan skor pengukuran kualitas hidup sebesar 122,7. Simpulan: Kualitas hidup manusia lanjut usia pengguna gigi tiruan di Kecamatan Wanea umumnya tergolong baik.
\end{abstract}

Kata kunci: kualitas hidup, lansia, pengguna gigi tiruan 
Menjadi tua atau menua merupakan proses alami yang tidak dapat dihindari oleh setiap makhluk hidup termasuk manusia. Proses ini akan berjalan terus menerus dan berkesinambungan seiring dengan kehidupan. ${ }^{1}$

Pada manusia lanjut usia (lansia) kemampuan jaringan untuk memperbaiki diri hilang secara perlahan-lahan; demikian halnya dengan kemampuan untuk mempertahankan fungsi normalnya sehingga tidak dapat bertahan terhadap infeksi dan memperbaiki kerusakan yang diderita. ${ }^{2}$ Kemunduran jaringan yang terjadi pada lansia terkait juga dengan jaringan dalam mulut. Semakin lanjut usia seseorang, kondisi jaringan dalam mulut akan mengalami perubahan; salah satunya ialah meningkatnya risiko kehilangan gigi. ${ }^{3}$

Indonesia merupakan salah satu negara berkembang dan mengalami jumlah ledakan penduduk lansia. Sulawesi Utara sebagai salah satu provinsi di Indonesia memiliki jumlah lansia sebesar $8,45 \%$ dan menduduki posisi ke-5 jumlah lansia terbanyak dari provinsi yang lain. ${ }^{4}$ Banyaknya penduduk yang berusia lansia akan meningkatkan kebutuhan akan pembuatan gigi tiruan akibat besarnya risiko kehilangan gigi. Hilangnya seluruh gigi atau sebagian mempunyai efek yang sama terhadap kecacatan hidup. Pembuatan gigi tiruan sebagai pengganti gigi yang hilang merupakan solusi untuk pemulihan estetika dan kondisi fungsional penderita. ${ }^{5.6}$

Gigi lepasan maupun gigi tiruan cekat pada hakekatnya dibuat untuk memperbaiki fungsi pengunyahan, pengucapan, estetis, menjaga kesehatan jaringan serta mencegah kerusakan lebih lanjut dari struktur organ dalam rongga mulut. ${ }^{7}$ Penggunaan gigi tiruan memiliki manfaat untuk memperbaiki kualitas hidup penggunanya. Hasil penelitan oleh Emini ${ }^{8}$ menunjukkan bahwa terdapat perbedaan bermakna pada kualitas hidup sebelum dan sesudah pemakaian gigi tiruan.

Kualitas hidup merupakan suatu komponen yang kompleks, mencakup usia harapan hidup. Hidup yang berkualitas merupakan sesuatu yang sangat diinginkan lansia. Hidup lansia yang berkualitas merupakan kondisi fungsional lansia pada kondisi optimal,sehingga mereka bisa menikmati masa tuanya dengan penuh makna, membahagiakan dan berguna.,

Pemakaian gigi tiruan diharapkan dapat meningkatkan rasa percaya diri dalam bersosialisasi dan dapat meningkatkan kualitas hidup lansia. Kenyataan yang ada tidak semua gigi tiruan yang digunakan dapat memenuhi harapan penggunanya. Keluhan yang timbul bermacam-macam, antara lain rasa sakit saat digunakan, gigi tiruan yang digunakan longgar, tidak stabil serta menganggu fungsi bicara.

Masalah yang ada mendorong penulis untuk meneliti tentang kualitas hidup lansia pengguna gigi tiruan yang berada di kecamatan Wanea kota Manado. Penulis memilih kecamatan Wanea sebagai lokasi penelitian karena kecamatan Wanea merupakan kecamatan dengan penduduk terbanyak di kota Manado dan pada survei awal ditemukan cukup banyak lansia yang menggunakan gigi tiruan untuk menggantikan giginya yang hilang.

\section{BAHAN DAN METODE PENELITIAN}

Jenis penelitian ini ialah deskriptif dengan desain potong lintang. Penelitian dilaksanakan di Kecamatan Wanea pada bulan Februari-Agustus 2016. Sampel penelitian ini yaitu lansia yang memakai gigi tiruan. Penilaian kualitas hidup dilakukan dengan menggunakan kuesioner kualitas hidup. Data diolah dan disajikan berdasarkan distribusi dalam bentuk Tabel.

\section{HASIL PENELITIAN}

Karakteristik respoden penelitian ini dapat dilihat pada Tabel 1-6.

Tabel 1. Karakteristik responden penelitian berdasarkan usia

\begin{tabular}{ccc}
\hline Usia & $\mathrm{n}$ & $\%$ \\
\hline 55-64 tahun & 22 & 28,6 \\
$\geq 65$ tahun & 55 & 71,4 \\
Jumlah & 77 & 100 \\
\hline
\end{tabular}


Tabel 2. Karakteristik responden penelitian berdasarkan jenis kelamin

\begin{tabular}{ccc}
\hline Jenis kelamin & $\mathrm{n}$ & $\%$ \\
\hline Laki-laki & 26 & 33,8 \\
Perempuan & 51 & 66,2 \\
Jumlah & 77 & 100 \\
\hline
\end{tabular}

Tabel 3. Karakteristik responden berdasarkan tingkat pendidikan

\begin{tabular}{ccc}
\hline Pendidikan & $\mathrm{n}$ & $\%$ \\
\hline SD & 7 & 9,1 \\
SMP & 9 & 11,7 \\
SMA & 36 & 46,7 \\
Akademi & 3 & 3,9 \\
Sarjana & 22 & 28,6 \\
Total & 77 & 100,0 \\
\hline
\end{tabular}

Tabel 4. Karakteristik responden berdasarkan lama pemakaian gigi tiruan

\begin{tabular}{ccc}
\hline $\begin{array}{c}\text { Lama Pemakaian } \\
\text { Gigi Tiruan }\end{array}$ & $\mathrm{n}$ & $\%$ \\
\hline$<5$ tahun & 32 & 41,5 \\
$5-9$ tahun & 19 & 24,7 \\
$>10$ tahun & 26 & 33,8 \\
Total & 77 & 100 \\
\hline
\end{tabular}

Tabel 5. Karakteristik responden berdasarkan jenis gigi tiruan

\begin{tabular}{ccc}
\hline $\begin{array}{c}\text { Jenis gigi } \\
\text { tiruan }\end{array}$ & $\mathrm{n}$ & $\%$ \\
\hline GTSL & 38 & 49,4 \\
GTP & 39 & 50,6 \\
Total & 77 & 100,0 \\
\hline
\end{tabular}

Tabel 6. Karakteristik responden berdasarkan tempat pembuatan gigi tiruan

\begin{tabular}{ccc}
\hline $\begin{array}{c}\text { Tempat pembuatan } \\
\text { gigi tiruan }\end{array}$ & $\mathrm{n}$ & $\%$ \\
\hline Dokter Gigi & 27 & 35,1 \\
Perawat Gigi & 5 & 6,5 \\
Tukang Gigi & 45 & 58,4 \\
Total & 77 & 100,0 \\
\hline
\end{tabular}

Tabel 7 memperlihatkan distribusi frekuensi kualitas hidup responden berdasarkan penilaian 7 dimensi kualitas hidup.
Tabel 7. Distribusi frekuensi kualitas hidup responden berdasarkan penilaian seluruh dimensi kualitas hidup

\begin{tabular}{clc}
\hline No. & $\begin{array}{l}\text { Dimensi kualitas } \\
\text { hidup }\end{array}$ & $\begin{array}{c}\text { Skor rata-rata } \\
\text { per dimensi }\end{array}$ \\
\hline 1 & Keterbatasan fungsi & 151,5 \\
2 & Rasa sakit fisik & 148 \\
3 & $\begin{array}{l}\text { Ketidaknyamanan } \\
\text { psikis }\end{array}$ & 112 \\
& $\begin{array}{l}\text { Ketidakmampuan } \\
4\end{array}$ & 140 \\
& $\begin{array}{l}\text { fisik } \\
5\end{array}$ & $\begin{array}{l}\text { Ketidakmampuan } \\
\text { psikis }\end{array}$ \\
& $\begin{array}{l}\text { Ketidakmampuan } \\
6\end{array}$ & 106 \\
7 & $\begin{array}{l}\text { sosial } \\
\text { Keterhambatan }\end{array}$ & 99,5 \\
& Skor rata-rata \\
& $\begin{array}{l}\text { dimensi kualitas } \\
\text { hidup }\end{array}$ & 102,5 \\
\hline & & 122,7 \\
\hline
\end{tabular}

\section{BAHASAN}

Hasil penelitian menunjukkan bahwa responden pengguna gigi tiruan terbanyak berada pada kelompok usia 65 tahun ke atas, diikuti kelompok umur 55-64 tahun. Hal ini menunjukkan pada kelompok usia 65 tahun ke atas banyak yang telah mengalami kehilangan gigi dibandingkan kelompok usia di bawahnya. Semakin bertambahnya usia seseorang, maka kondisi jaringan mengalami penurunan, termasuk jaringan dalam mulut. Organ tubuh termasuk gigi geligi juga semakin rentan terhadap kerusakan, oleh karena lebih banyak digunakan atau difungsikan. ${ }^{11}$

Responden pada penelitian ini seluruhnya berjumlah 77 orang, dan yang terbanyak berjenis kelamin perempuan. Pemakai gigi tiruan yang berjenis kelamin perempuan jauh lebih banyak disebabkan karena perempuan umumnya lebih peduli terhadap estetika termasuk penampilan. Hal ini sejalan dengan penelitian oleh Agniti ${ }^{12}$ yang menunjukkan bahwa persentase pengguna gigi tiruan yang berjenis kelamin perempuan di Indonesia lebih banyak dibandingkan dengan laki-laki. ${ }^{1}$

Data hasil penelitian selanjutnya menunjukkan bahwa sebagian besar responden menempuh pendidikan tingkat SMA diikuti dengan tingkat pendidikan 
sarjana. Pendidikan yang baik membuat responden mudah memahami dan lebih peduli pada kesehatan gigi dan mulut oleh karena pengetahuan yang dimilikinya. Individu dengan pendidikan setingkat SMA umumnya sudah memiliki pengetahuan yang cukup untuk kesehatan gigi dan mulut. Pengetahuan yang dimiliki tentang kesehatan gigi dan mulut akan berkaitan dengan kepedulian responden terhadap kesehatan gigi dan mulut serta penampilan. Adanya pemahaman tentang pentingnya keberadaan gigi berkaitan dengan fungsinya akan menyebabkan responden yang mengalami kehilangan gigi memutuskan untuk memakai gigi tiruan.

Pada penelitian ini diperoleh data bahwa responden terbanyak memakai gigi tiruan dalam kurun waktu kurang dari 5 tahun. Data hasil penelitian ini menunjukkan sebanyak 38 responden memakai GTSL dan 39 responden yang memakai GTP. Hasil ini menunjukkan bahwa jumlah responden yang kehilangan gigi sebagian dan kehilangan gigi seluruhnya kurang lebih berimbang. Kehilangan gigi antara lain dipengaruhi oleh pengetahuan responden terhadap pemeliharaan kesehatan gigi dan mulut, pemeliharaan kesehatan gigi dan mulut yang kurang akan lebih mudah mengalami kerusakan dan tanggalnya gigi, sehingga, gigi yang tanggal harus diganti dengan gigi tiruan untuk mengembalikan fungsi yang hilang. Pada lansia, kehilangan gigi bukan saja dipicu oleh perilaku lansia dalam pemeliharaan kesehatan gigi dan mulut, namun oleh usia dan kondisi sistemik. Semakin lanjut usia seseorang, maka risiko kehilangan gigi akan semakin besar. Demikian halnya dengan kondisi sistemik pada lansia, usia yang lanjut akan menyebabkan terjadinya berbagai perubahan pada kondisi sistemiknya. Perubahan yang terjadi dapat menyebabkan berbagai gangguan, salah satunya berupa penyakit diabetes melitus yang berdampak pada kehilangan gigi sehingga membutuhkan pemakaian gigi tiruan.

Data penelitian menunjukan bahwa pemasangan gigi tiruan paling banyak di tukang gigi dengan jumlah 45 responden.
Lansia pada penelitian ini cenderung memilih tukang gigi untuk membuat gigi tiruan dikarenakan harga yang jauh lebih murah daripada ke dokter gigi, bahkan masih banyak lansia yang masih sulit untuk membedakan antara dokter gigi dan tukang gigi. Hal ini sama halnya dengan penelitian Anggreini ${ }^{13}$ yang menyatakan bahwa biaya yang relatif murah menjadi salah satu faktor utama dalam memanfaatkan jasa tukang gigi dibandingkan dengan pelayanan kesehatan gigi lainnya. Hasil penelitian ini juga sejalan dengan penelitian Ramahyani et al. ${ }^{14}$ yang menyatakan masyarakat masih beranggapan bahwa tukang gigi mempunyai profesi yang sama seperti halnya dokter gigi.

Akibat kehilangan gigi, seseorang dapat mengalami kesulitan dalam pengucapan kata atau kalimat dan merasa tidak dapat mengecap rasa dengan baik sehingga dapat mengganggu kualitas hidup. Demikian halnya pada lansia, kehilangan gigi yang berjalan seiring dengan pertambahan usia akan menyebabkan lansia membutuhkan pemakaian gigi tiruan. Diharapkan lewat pemakaian gigi tiruan, fungsi yang hilang akibat kehilangan gigi dapat dikembalikan.

Pada penilaian dimensi keterbatasan fungsi, sebagian besar reponden merasa tidak pernah merasa kesulitan dalam pengucapan kata atau kalimat dan tidak pernah pernah merasa tidak dapat mengecap rasa dengan baik. Hal ini disebabkan sebagian besar responden cukup puas dengan gigi tiruan yang dipakai. Gigi tiruan yang baik juga dapat membantu mengembalikan fungsi fonetik dan membantu meningkatkan efiensi pengunyahan yang juga akan meningkatkan kemampuan pengecapan. ${ }^{15}$ Hasil penilaian kualitas hidup lansia berdasarkan dimensi keterbatasan fungsi memperoleh skor ratarata sebesar 151,5 dan tergolong pada kategori baik.

Adanya gangguan berupa rasa sakit dalam rongga mulut ketika memakai gigi tiruan disebabkan karena desain gigi tiruan yang kurang baik. Hasil penelitian yang dilakukan oleh Carmen $^{16}$ menyimpulkan 
adanya rasa sakit dan tidak nyaman pada penggunaan gigi tiruan memberi dampak yang kurang baik terhadap kualitas hidup seseorang. Hal ini dapat menimbulkan ketidaknyamanan ketika mengunyah tetapi sebagian besar responden merasakan hanya diawal saja pada saat pemakaian responden merasakan susah untuk mengunyah karena perlu penyesuaian dan selebihnya tidak masalah. Hasil penilaian kualitas hidup berdasarkan dimensi rasa sakit fisik menunjukkan bahwa sebagian besar responden tidak pernah merasa sakit dalam rongga mulut dan tidak pernah merasakan ketidaknyamanan saat mengunyah. Hasil ini menunjukkan bahwa kualitas hidup lansia pengguna gigi tiruan tergolong baik dengan skor penilaian sebesar 148. Hasil selanjutnya menunjukkan penilaian kualitas hidup lansia berdasarkan ketidakmampuan psikis didapatkan dari 77 responden, jumlah reponden yang tidak pernah mengalami cemas atau khawatir 54 responden dan 52 responden tidak pernah merasakan tegang. Hal ini disebabkan karena responden telah mampu menyesuaikan diri dan merasa nyaman dengan gigi tiruan yang dipakai, sehingga ketika gigi tiruan digunakan untuk berbicara, mengunyah atau berada pada lingkungan sosial responden tidak merasa cemas dan tegang. Kenyamanan penggunaan gigi tiruan dipengaruhi oleh kualitas dari gigi tiruan yang dibuat. Gigi tiruan yang memiliki kualitas yang baik mampu mengembalikan fungsi yang hilang akibat kehilangan gigi. Hasil penilaian kualitas hidup lansia berdasarkan dimensi ketidaknyamanan psikis memperoleh skor rata-rata 112 dan tergolong pada kategori baik.

Pada penilaian kualitas hidup berdasarkan ketidakmampuan fisik menunjukkan bahwa sebagian besar responden menyatakan tidak pernah merasa makanan yang dikonsumsi kurang memuaskan dan terhenti saat makan oleh karena masalah yang ditimbulkan oleh pemakaian gigi tiruan. Hal ini disebabkan karena sebagian besar responden merasa gigi tiruan dianggap sama seperti gigi asli sehingga responden sangat puas pada gigi tiruan yang dipakai. Hasil penilaian ini menggambarkan bahwa gigi tiruan yang digunakan dapat difungsikan dengan baik saat mengunyah makanan. Pembuatan gigi tiruan yang dilakukan dengan memperhatikan prinsip-prinsip faal pengunyahan akan menghasilkan gigi tiruan yang mampu difungsikan dengan baik saat mengunyah makanan. Disamping itu bentuk gigi tiruan yang dibuat dengan ukuran yang tepat, akan menyebabkan gerakan lidah tidak terganggu dan tetap stabil saat mengunyah. Hasil penilaian kualitas hidup lansia berdasarkan dimensi ketidakmampuan fisik memperoleh skor rata-rata 140 dan tergolong baik.

Pada lansia seiring bertambahnya usia, maka lansia akan lebih banyak mengurung diri dan tidak ingin bergaul dengan yang lain. Lansia akan mengalami kesulitan merasa rileks dan mudah merasa malu. ${ }^{14}$ Kondisi ini antara lain bisa disebabkan karena adanya berbagai gangguan yang terjadi pada lansia, antara lain adanya kehilangan gigi. Akibat kehilangan gigi lansia sulit untuk rileks karena ketika akan berinteraksi dengan orang lain, lansia mengalami rasa rendah diri karena adanya gigi yang hilang. Ketidakmampuan untuk melafalkan kata-kata dengan jelas dan kesulitan ketika akan mengunyah makanan dapat memicu stres. Pada saat lansia memakai gigi tiruan, berdasarkan hasil penelitian pada dimensi ketidakmampuan psikis, didapatkan bahwa sebagian besar responden tidak pernah kesulitan merasa rileks dan tidak pernah merasa malu. Hal ini disebabkan karena rersponden merasa lebih percaya diri dibandingkan ketika tidak memakai gigi tiruan. Hasil ini menggambarkan bahwa pemakaian gigi tiruan mampu menghilangkan rasa stres akibat kehilangan gigi dan mengembalikan rasa pecaya diri responden. Hasil penelitian kualitas hidup lansia berdasarkan dimensi ketidakmampuan psikis memperoleh skor rata-rata 106 dan tergolong pada kategori penilaian baik.

Pada dimensi ketidakmampuan sosial lansia akan mudah merasa tersinggung dan 
sulit mengerjakan pekerjaan sehari-hari ini dikarenakan pada usia lanjut, lansia akan mengalami perubahan psikososial dimana lansia merasa tidak yakin pada diri sendiri dan kurangnya dukungan sosial. Hal ini dipicu oleh berbagai gangguan yang dapat terjadi pada lansia seiring dengan bertambahnya usia, salah satunya kehilangan gigi. Pada saat lansia memakai gigi tiruan didapatkan hasil penilaian dimensi ketidakmampuan sosial dengan skor 99,5 yang tergolong baik. Hasil yang diperoleh dikarenakan responden merasa lebih percaya diri untuk melakukan aktivitas sosial mereka dibandingkan ketika tidak memakai gigi tiruan; dengan kata lain pemakaian gigi tiruan memiliki dampak yang baik terhadap kualitas hidup. Pada penelitian didapatkan bahwa banyak orang tidak ingin terlihat ompong dan memakai gigi tiruan agar tidak malu berinteraksi dengan orang lain. Hasil ini sejalan dengan penelitian yang dilakukan oleh Emini ${ }^{8}$ yang menyimpulkan bahwa sebelum mengganti gigi yang hilang dengan gigi tiruan seseorang merasa kurang percaya diri, membatasi aktivitas sosial dan menghindari hubungan personal namun setelah memakai gigi tiruan seseorang merasa lebih percaya diri dalam menjalani aktivitas sosialnya. ${ }^{8}$

Pada penilaian kualitas hidup berdasarkan dimensi keterhambatan, menunjukkan bahwa sebagian besar responden tidak pernah merasa hidup terasa kurang memuaskan dan tidak dapat melakukan pekerjaan sehari-hari. Hal ini disebabkan karena pemakaian gigi tiruan tidak mengganggu kehidupan responden secara keseluruhan. Hasil ini memberikan gambaran bahwa secara umum gigi tiruan yang digunakan mampu memenuhi harapan responden. Artinya bahwa responden merasa puas dengan gigi tiruan yang digunakan. Kepuasan responden bukan didasarkan pada kualitas gigi tiruan yang memenuhi standar pembuatan, namun didasarkan atas penilaian responden sebagai pengguna gigi tiruan. Ketika responden merasa bahwa gigi tiruan yang digunakan mampu memenuhi harapannya, maka responden akan puas. Hasil penilaian kualitas hidup masyarakat berdasarkan dimensi keterhambatan memperoleh skor rata-rata sebesar 102,5 dan tergolong pada kategori baik.

Hasil penilaian seluruh dimensi menunjukkan 7 dimensi OHIP mengenai keterbatasan fungsi, rasa nyeri fisik, ketidaknyamanan psikis, ketidakmampuan fisik, ketidakmampuan psikis, ketidakmampuan sosial dan keterhambatan, semuanya tergolong baik dengan skor ratarata 122,7. Hasil ini menunjukkan bahwa lansia yang memakai gigi tiruan memiliki kualitas hidup yang baik. Hal ini sejalan dengan hasil penelitian Hussain ${ }^{17}$ yang menyimpulkan bahwa pemakaian gigi tiruan penting untuk mendapatkan kualitas hidup yang lebih baik dan secara langsung memiliki dampak positif terhadap aktivitas sosial, mental dan psikologi.

\section{SIMPULAN}

Berdasarkan hasil penelitian kualitas hidup manusia lanjut usia pengguna gigi tiruan di Kecamatan Wanea secara umum tergolong baik dan secara khusus kualitas hidup lansia berdasarkan tujuh dimensi tergolong baik.

\section{SARAN}

1. Diharapkan bagi institusi pemerintah dalam hal ini dinas kesehatan dan puskesmas dapat menggunakan informasi dalam penelitian ini untuk kepentingan promosi kesehatan tentang pentingnya pemakaian gigi tiruan untuk meningkatkan kualitas hidup masyarakat

2. Perlu dilakukan penelitian sejenis dengan melibatkan populasi yang lebih luas untuk memperoleh hasil yang lebih mendekati kondisi sebenarnya.

3. Perlunya penyuluhan mengenai kesehatan gigi dan mulut kepada lansia khususnya lansia yang menggunakan gigi tiruan tentang cara merawat gigi tiruan serta risiko penggunaan gigi tiruan yang dibuat oleh tukang gigi.

DAFTAR PUSTAKA

1. Kusumayanti D. Gerontik. Jurnal Gerontik 
(D1). 2011:2.

2. Padila. Buku Ajar Keperawatan Gerontik. Medical book. Yogyakarta: Medical Book, 2013; p. 4.97.

3. Vargas CM, Kramarow EA, Yelloitz JA. The oral health of older Americans. Aging trends. National center for health statistics. 2001; p.1-8.

4. Gambaran kesehatan lanjut usia di Indonesia. Buletin Data dan Informasi Kesehatan. 2013; p.2.

5. Rahmayani L, Herwanda, Idawani $M$. Perilaku pemakai gigi tiruan terhadap pemeliharaan kebersihan gigi tiruan lepasan. Jurnal PDGI. 2013:62(3):83.

6. Peracini A, de Andrare I, de Freitas HOP, da Silva CHL, de Souza RF. Behavior and hygiene habits of complete denture wearers. Brazillian Dent J. 2010:21(3):2.

7. Tarigan S. Pasien prostodonsia lanjut usia beberapa pertimbangan dalam perawatan [Tesis]. Medan; Universitas Sumatra Utara; 2005.

8. Emini. Gigi tiruan dan perilaku ibadah. Jurnal Health Quality. 2013;4(1):28.

9. Sutikno E. Hubungan antara fungsi keluarga dan kualitas hidup lansia [Tesis]. Surakarta: Program Pasca Sarjana Universitas Sebelas Maret, 2011.

10. Tjahja I,N Ghani L. Status kesehatan gigi dan mulut ditinjau dari faktor individu pengunjung puskesmas DKI Jakarta tahun 2007. Buletin Penelitian Kesehatan. 2010;38(2): 52-66.

11. But AM, Bilahlahmed, Parveen N. Oral health related quality of life in complete denture. Pakistan Oral and Dental Journal; 2009:29(2):136.

12. Agniti MD. Persentase pengguna gigi tiruan di Indonesia. Media Litbang Kesehatan. 2010;XX(2).

13. Kaunang W, Supit A, Angraeni A. Persepsi masyarakat terhadap pembuatan gigi tiruan oleh tukang gigi di desa Treman kecamatan Kauditan. Manado: Program Studi Kedokteran Gigi Universitas Sam Ratulangi, 2015; p. 8.

14. Rahmayani L, Ifandi, Hasanah I. Analisis pemakaian jasa pemasangan gigi tiruan sebagian lepasan akrilik pada tukang gigi dan tukang gigi di Banda Aceh. Jurnal PDGI. 2012;61(2):77.

15. Krunic N, Kostic M, Petrovic M. Oral health-related quality of life of edentulous patients after complete denture relining. Serbia: Clinic of Dentistry. Vojno Sanit Pregl. 2015; 72(4):307-11.

16. Perea C, Suarez-Gracia MJ, Del Rio J, Torres-Lagares D, Montero J, Maria J, et al. Oral health related quality of life in complete denture wearers depending on their sociodemographic background, prosthetic-related factors and clinical condition. Med Oral Patol Oral Cir Bucal; 2013:18(3):e371-80.

17. Hussain SZ, Shujaat NG, Idris SH. Oral health related quality of life (OHRQoL) in 40 to 70 years. Pak Oral Dental J. 2010;30(2):530. 